\title{
PAPILDOMOSIOS IR ALTERNATYVIOSIOS MEDICINOS REGLAMENTAVIMAS LIETUVOJE: PROBLEMOS IR PERSPEKTYVOS
}

\author{
Brigita Kreiviniené $\dot{e}^{1}$, Jolanta Vaičiuliené $\dot{1}^{1}$, Sigutė Norkienè $\dot{e}^{1-2}$, Gitana Skirutienè ${ }^{1}$ \\ ${ }^{1}$ Klaipedos universitetas, ${ }^{2}$ Klaipèdos jūrininku ligonine
}

Raktažodžiai: papildomoji ir alternatyvioji medicina, reglamentavimas, gerovè.

\section{Santrauka}

Lietuvoje ir visoje Europoje pastebimas papildomosios ir alternatyviosios medicinos (toliau - PAM) paslaugų poreikio augimas, suvokiamas išnaudojimo potencialas, esant reglamentuotai teisinei bazei. Diskusijos kyla dèl PAM sąvokos, sričiu apibrèžties, kuriamų paslaugų teikimo metodikų, vadinamujjų standartų, specialistų kvalifikacijos, licencijavimo tvarkos. Darbo tikslas - išanalizuoti dabartinę papildomosios ir alternatyviosios medicinos reguliavimo situaciją, esančias problemas bei galimas perspektyvas. Atlikta mokslinès literatūros analizè, apžvelgiant sveikatos, žmogaus gerovès, esmines PAM terminijas. Pateikiamos įžvalgos iš šiandienos Sveikatos apsaugos ministerijoje svarstomų teisinio reguliavimo dokumentų bei numatomų scenarijų. Tyrimo rezultatai leidžia teigti, kad Pasaulio sveikatos organizacija apibrèžia žmogaus sveikatą kaip visapusę fizinę, socialinę ir dvasinę gerovę, orientuojantis, jog sveikata yra holistinès medicinos sampratos sąvoka. Europos Sajungos sveikatos strategijoje (trečioji programa 2014-2020) kalbama apie žmogaus sveikatingumą, prevenciją, rekreacines sveikatos funkcijas, užtikrinant jų integraciją i visų sričių politiką. PAM galètų tapti sveikatos sampratos holistiškumo aspektu, kuomet per nustatytus sveikatinimo pogrupius būtų igyvendinamos rekreacijos, natūralios medicinos ir liaudies medicinos bei kita papildomosios ir alternatyviosios medicinos veiklos. Svarbu kalbeti apie tradicinès ir papildomosios bei alternatyviosios medicinos integralumą. Mokslinio diskurso analizè atskleidè, jog Europos šalyse yra pasirinktos skirtingos papildomosios ir alternatyviosios medicinos reglamentavimo stra- tegijos su tam tikrais bendrumais, taip pat skirtingos ir medicininès veiklos sritys pasaulio šalyse yra laikomos papildomaja ir alternatyviaja medicina. Kaip atsvaros tašku būtina laikytis Pasaulinès sveikatos organizacijos siūlomos krypties bei Europos regiono komiteto metinès sesijos $(2012 \mathrm{~m}$.) priimtos Europos sveikatos politikos strategijos „Sveikata 2020 “, kurioje yra numatomas integralumas bei holistinis sveikatos supratimas.

\section{İvadas}

Pirminiame LR sveikatos sistemos įstatyme (1994 m.) buvo numatyta holistinè sveikatos sampratos prieiga, suformuota vadovaujantis Pasaulio sveikatos organizacijos išplèstiniu sveikatos supratimu, kuomet orientuojamasi ne tik ị fizinę, bet ir ị dvasinę, socialinę gerovę [1]. Šiandien sveikatos samprata yra ịgavusi dar aiškesnị socialini konceptą - diskutuojama apie sveikatos bei ekonominio produktyvumo sąryšius, sveikatos situacijos netolygumu sąsajas su ekonominiu regionų išsivystymu, atskirties situacijos formavimąsi bei gyvenimo kokybès arba bendrosios žmogaus gerovès supratimą [2], t.y. gerovès sąvoka igavusi dar daugiau psichosocialinių bruožų medicininèje terminologijoje. Tradicinès (arba konvencinès) ir PAM integralumo klausimas itin aktualus šiandienos medicinos reglamentavimo sistemoje, kadangi Sveikatos apsaugos ministerija, igyvendindama XVI Vyriausybès programos nuostatą „siekti teisès aktais reglamentuoti netradicinès (papildomosios ir alternatyviosios) medicinos paslaugu teikimą“ pateikè „prioritetinès teisèkūros iniciatyvą - reglamentuoti netradicinès medicinos praktiką - numatomo teisinio reguliavimo poveikio vertinimo pažymą" [3]. Šiuo metu ne tik Lietuvoje, tačiau ir visoje Europoje pastebimas papildomosios ir alternatyviosios medicinos paslaugu poreikio augimas [4], suvokiamas ir papildomosios bei alternatyviosios medicinos išnaudojimo potencialas, esant reglamentuotai teisès bazei [5]. Dél šių 
priežasčių poreikis reglamentuoti bei reguliuoti PAM yra nekvestionuojamas. Vis dèlto diskusinių klausimų šiame etape kyla nemažai - nuo pačios PAM sąvokos ir sričių apibrežties iki kuriamų paslaugų teikimo metodikų arba vadinamųjų standartų, kaip ir specialistų kvalifikacijos, licencijavimo tvarkos ar pačios PAM apimties. I. Špokienès [4] požiūriu, nelicencijuotos PAM paslaugos yra pirmiausia neteisètos, teoriškai nepripažįstamos nei kaip gydymas, ar medicina, ar tuo labiau sveikatos priežiūra. Sveikatos apsaugos ministerijos pateiktoje pažymoje [3] taip pat buvo minèta galima žala žmogui dèl nelicencijuotų paslaugų, tačiau LR Vyriausybès kanceliarijos išvadoje [3] minima, jog pažymos rengejjai realiai negali pateikti galimas rizikas pagrindžiančių duomenų, todèl jos laikytinos labiau teorinemis-hipotetinėmis ar spekuliatyviomis, nei grịstomis ịrodymais. Vis dèlto reikètų nepamiršti saugumo kaip esminio Pasaulio sveikatos organizacijos globaliai deklaruojamo prioriteto, kuris buvo apibrèžtas 2002 metais pacientų saugumo iniciatyvoje [6].

Teisèkūros iniciatyvos pažymoje [3] buvo pateikiamos dvi galimos reglamentavimo alternatyvos bei galimas šio reglamentavimo poveikis administracinei naštai, ekonomikai, teisinei sistemai, socialinei sistemai bei viešajam administravimui. Vyriausybès pritarimas antrosios alternatyvos ịgyvendinimui iš esmès reiškia perejjimą prie palaipsninio netradicinès medicinos reguliavimo valstybiniu lygiu [7]. Tai reiškia, jog PAM arba sveikatinimo veiklos būtų integruotos ị bendrą Lietuvos sveikatos sistemą bei turès atitikti pagrindinius sveikatinimo veiklos principus. Šiuo reglamentavimu siekiama vadovautis sukurta tokios veiklos praktika, kuri egzistuoja ir kitose ES šalyse, tokiose kaip Vokietija, Vengrija, Malta, Danija, Belgija, Bulgarija ir kt. Tiesa, būtina pažymèti, jog PAM yra vadinamoji skètinè sąvoka, kuri apima gana ịvairius metodus, gydymo, terapijos ar net sveikatinimo sistemas. Taip pat, jog dabartyje egzistuoja PAM klasifikavimo pliuralizmas [8]. Pasaulio sveikatos organizacijos nutarimu [6], dar 2012 m. PAM apspręsta, kaip laikytina atskira medicinos bei sveikatos apsaugos sistemos dalimi, labiau nei integralia konvencinès arba tradicinès medicinos dalimi. Tokio sprendimo priežastys glūdi daugiausia nuolatines diskusijas kylančiuose klausimuose balansuojant tarp: saugumo/teigiamo poveikio/pakenkimo bei integralios medicinos (t.y., kuomet konvencinè medicina yra derinama su papildomosios ir alternatyviosios medicinos metodais) [9]. Taigi, galima teigti, jog Lietuvoje nepakanka tyrimų bei nèra mokslinio diskurso pliuralizmo papildomosios ir alternatyviosios medicinos reglamentavimo klausimais, aptariant esančias/galimas problemas bei numatant perspektyvas.
Tyrimo tikslas - išanalizuoti papildomosios ir alternatyviosios medicinos reglamentavimo klausimus, numatant problemas bei perspektyvas.

\section{Tyrimo medžiaga ir metodai}

Tyrimo metodologija grindžiama kritiniu mąstymu bei diskurso aptarimu. Diskursas šiame kontekste suprantamas kaip tam tikros gairès ar „rèmai“, „kognityvios schemos“, kurios išreiškia tam tikrų visuomenès grupių strategines pastangas nurodyti, suformuluoti bendrą reiškinio supratimą, kuris legitimuoja ir motyvuoja kolektyvinị veiksmą [10]. Straipsnyje yra taikoma sisteminè mokslinès literatūros analizè, dokumentų turinio analizè.

\section{Rezultatai}

Sveikatos rekreacijos koncepto turinys. Ieškant tinkamos PAM apibrèžties bei PAM paslaugų reglamentavimo apibrèžties, būtina turèti atsvaros tašką. Tai galètų būti sąlyginis konvencinès medicinos apibrěžimas. Tradicinè medicina yra suprantama kaip dabartinès Vakarų civilizacijos mokslo pasiekimais ir šių priemonių taikymą reglamentuojančia teise besiremianti sveikatos sutrikimų pažinimo, prevencijos, diagnostikos ir gydymo priemonių visuma [4]. Papildomosios ir alternatyviosios medicinos pažymos 1 priede [3] yra apibréžiamos plačios trys sritys, kurios teoriškai turètų aprèpti visą šiai dienai aktualų PAM paslaugų spektrą: sveikatos rekreacija, natūrali ir liaudies medicina bei kita PAM veikla. Autorių [5,8], analizuojančių PAM klausimus, skirstyme, pats papildomosios ir alternatyviosios medicinos turinys yra operacionalizuojamas kitokiu principu, t.y. siejant su konvencinès medicinos sąlyčiu. M. Wiese ir kt. [11] skiria tris PAM modelio tipus: inkorporaciją, integraciją bei pliuralizaciją, užtikrinant paciento pasirinkimo galimybę. Iš kitos pusès, PAM integralumo prielaidos iš esmès yra priklausančios ir nuo konvencinès medicinos atstovų požiūrio taikyti PAM metodus $[4,5,8]$. Išskiriama PAM turinio operacionalizacija, siejant ją su konvencinès medicinos sąlyčiu [8]: papildomoji medicina (metodai naudojami lygiagrečiai su konvencine medicina), alternatyvioji medicina (PAM naudojama vietoje konvencinès medicinos), integratyvioji medicina (konvencinè medicina integruojama su PAM), natūralioji medicina (bet kuri netradicinè medicina) bei holistiné medicina (i žmogų žiūrima kaip ị visumą, apimant jo fizinę sveikatą, gerovę, gyvenimo būdą, aplinką, mitybą, protinę, emocinę ir dvasinę sveikatą). Analizuojant šiandienos PAM reglamentavimo kontekstą bei paslaugų turinį, būtina atsižvelgti ị du veiksnius: sveikatos sampratą ir konvencinès medicinos sąsają (1 lentelè). 
1 lentelė. Planuojamos reglamentuoti PAM sričių paslaugų grupės turinio analizė parengta pagal Sveikatos apsaugos ministerijos 1 pažymą.

\begin{tabular}{|c|c|c|}
\hline $\begin{array}{l}\text { PAM srities } \\
\text { paslaugü } \\
\text { grupė [12] }\end{array}$ & $\begin{array}{l}\text { Diskutuojamas } \\
\text { turinys [12] }\end{array}$ & Siūlytinas tobulinimas \\
\hline $\begin{array}{l}\text { Sveikatos } \\
\text { rekreacija }\end{array}$ & $\begin{array}{l}\text { PAM sritis, skirta } \\
\text { fizinių ir dvasinių } \\
\text { jëgų atgavimui } \\
\text { (Visuomenès svei- } \\
\text { katos departamen- } \\
\text { to sąvoka) }\end{array}$ & $\begin{array}{l}\text { Paslaugos turinyje numatoma reglamentuoti fizinių pratimo, } \\
\text { meno terapijų, psichoemocinio poveikio ir kt. paslaugas, ku- } \\
\text { rios savo sudėtyje išlaiko ne tik rekreacinị (re-creation, angl. } \\
\text { - atstatymo, atkūrimo) turinị. Siūloma laikytis pirminio, išplès- } \\
\text { tinio turinio formuluotės [12]: fizinių ir dvasinių jègų atgavi- } \\
\text { mas, sveikatos saugojimas ir stiprinimas, sveikos gyvensenos } \\
\text { praktinių igūdžių tobulinimas. }\end{array}$ \\
\hline TURINYS & $\begin{array}{l}\text { Jègų atgavimas: } \\
\text { fizinių ir dvasinių }\end{array}$ & $\begin{array}{l}\text { Sergančio asmens jègų atgavimas: fizinių, dvasinių. } \\
\text { Sveiko asmens sveikatos saugojimas } \\
\text { Sveiko asmens sveikatos stiprinimas. Prevencinis sveikatini- } \\
\text { mas }\end{array}$ \\
\hline $\begin{array}{l}\text { TURINIO } \\
\text { ATITIKTIS } \\
\text { MODELIUI }\end{array}$ & $\begin{array}{l}\text { Alternatyvioji me- } \\
\text { dicina, natūralioji } \\
\text { medicina, konven- } \\
\text { cinè medicina }\end{array}$ & $\begin{array}{l}\text { Alternatyvioji medicina, natūralioji medicina, holistinè medi- } \\
\text { cina }\end{array}$ \\
\hline $\begin{array}{l}\text { Natūralioji } \\
\text { ir liaudies } \\
\text { medicina }\end{array}$ & $\begin{array}{l}\text { PAM sritis, skirta } \\
\text { ligos sukeltiems } \\
\text { negalavimams } \\
\text { palengvinti }\end{array}$ & $\begin{array}{l}\text { Paslaugos turinyje numatoma reglamentuoti balneoterapines, } \\
\text { peloido terapines, fitoterapijos, homeopatijos ir kt. paslaugas. } \\
\text { Siūloma laikytis išplèstinès formuluotès: PAM sritis, skirta } \\
\text { kaip pagrindinė ar papildoma priemonė ligos sukeltiems nega- } \\
\text { lavimams palengvinti arba padedanti palaikyti/atkurti žmogaus } \\
\text { fizinę ir psichosocialinę gerovę. }\end{array}$ \\
\hline TURINYS & $\begin{array}{l}\text { Liga, negalavimas, } \\
\text { gydymas }\end{array}$ & $\begin{array}{l}\text { Gydymas, integruota terapija, prevencija, reabilitacija: fizinè ir } \\
\text { psichologiné/socialiné }\end{array}$ \\
\hline $\begin{array}{l}\text { TURINIO } \\
\text { ATITIKTIS } \\
\text { MODELIUI }\end{array}$ & $\begin{array}{l}\text { Alternatyvioji me- } \\
\text { dicina, konvencine } \\
\text { medicina }\end{array}$ & $\begin{array}{l}\text { Alternatyvioji medicina, integratyvioji medicina, papildomoji } \\
\text { medicina, natūralioji medicina, holistinè medicina }\end{array}$ \\
\hline $\begin{array}{l}\text { Kita PAM } \\
\text { veikla }\end{array}$ & $\begin{array}{l}\text { PAM praktikos } \\
\text { veikla, kurios } \\
\text { metu sukuriami } \\
\text { produktai gali būti } \\
\text { naudojami PAM } \\
\text { veikloje }\end{array}$ & Tobulinimas nesiūlomas \\
\hline TURINYS & PAM produktas & \\
\hline $\begin{array}{l}\text { TURINIO } \\
\text { ATITIKTIS } \\
\text { MODELIUI }\end{array}$ & \multicolumn{2}{|l|}{ PAM visi modeliai } \\
\hline
\end{tabular}

Lentelèje pateiktos ižzalgos pagal PAM planuojamas paslaugų grupes, pateikiant svarstomus apibrèžimus bei pateikiant jų turinio ịžvalgas. Teisėkūros iniciatyvos reglamentavimo pažymoje [3] yra aprašomos planuojamos reglamentuoti PAM sritys: sveikatos rekreacija, natūralioji ir liaudies medicina bei kita papildomosios ir alternatyviosios medicinos sritis. Pažymoje sveikatos rekreacija apima [12]: gamtinių ir fizikinių poveikių grupę (pvz., balneoterapinių paslaugų pogrupis, performuotų fizikinių veiksnių paslaugų pogrupis ir kt.), mitybos paslaugų grupę (konsul- tavimo mitybos klausimais pogrupis), paslaugų, teikiamų gerai fizinei būklei užtikrinti, grupę (pvz., kūno priežiūros, veido priežiūros pogrupiai ir pan.), psichosocialinio poveikio paslaugų grupę (meno, gyvūnų terapijos, kt.), Rytų medicinos sistemų grupę (ajurveda, tradiciné kinų medicina). Šiuo metu planuojama, jog rekreacijos dalis liktų nelicencijuojama PAM dalimi, kuriai išliks savireguliacijos funkcijos.

Kalbant apie pačių sąvokų turini, Sveikatos apsaugos ministerijos - Visuomenès sveikatos departamento [12] 
siūloma sveikatos rekreacijos apibrèžtis iš esmès yra atkartojanti klinikinès konvencinès medicinos paslaugų turinį, kuomet taikomų priemonių visuma siekiama sugrąžinti sutrikusias funkcijas, jas kompensuoti arba palaikyti funkcinio pajègumo lygị [13]. Siūlomuose apibrèžimo tobulinimuose rekomenduotina laikytis ilgalaikès trukmès sveikatos strateginio planavimo dokumento gairių, numatant tikslus, uždavinius, kriterijus iki 2025 metų [14,15]. Lietuvos Respublikos Seimo 2014 m. birželio 26 d. nutarimu Nr. XII-964 patvirtintoje Lietuvos sveikatos 2014-2025 metu programoje numatoma, kokia kryptimi bus plètojama sveikatos politika, numatomi planuojami pasiekti kriterijai, taip pat ir planuojamos lèšos prioritetinèms sveikatos sritims [15]. Taigi, strategijos dokumente [14] išskiriami keturi strateginiai tikslai, orientuoti ị žmogaus gerovès stiprinimą ne tik fiziniais, bet ir psichosocialiniais parametrais:

1. Saugesnès socialinès aplinkos sukūrimas mažinant sveikatos netolygumus ir socialinę atskirtị.

2. Sveikatai palankios fizinès darbo ir gyvenamosios aplinkos sukūrimas.

3. Sveikos gyvensenos bei jos kultūros formavimas.

4. Kokybiškos bei efektyvios sveikatos priežiūros užtikrinimas, orientuotas į gyventojų poreikius.

Galima teigti, jog platesnis apibrèžimas, ịtraukiant prevencines sritis, labiau atlieptų Lietuvos sveikatos programos nuostatas bei užtikrintų holistinio modelio ịgyvendinimą. Juolab, Lietuvos sveikatos 2014-2025 metų programoje yra ịvardytos ir iki 2010 metų vykdytos sveikatos programos tokios nesėkmės kaip: nepakankamas tarpsektorinis bendradarbiavimas, mažas sveikos gyvensenos ipročių ugdymo priemonių efektyvumas, sunkus kai kurių sveikatos priežiūros paslaugų prieinamumas, sveikatos netolygumas bei racionali sveikatos sistemos išteklių paskirstymo problema [15]. Dèl šios priežasties, apsiribojant sąvoka „fizinių ir dvasinių jègų atgavimas“, formuojama neteisinga nuostata, kad pati paslaugos grupe orientuojasi i serganti asmeni, t.y. asmeniui nèra poreikio palaikyti ar stiprinti, tausoti, formuoti tinkamą sveikatos stiprinimo požiūrị, igūdžius ir pan. Platesnè koncepcija atlieptų ir Pasaulio sveikatos organizacijos konstitucijos preambulejje skelbiamą sveikatos apibrèžimą, kuriame numatoma, jog „sveikata yra visuminé fiziné, socialinè ir psichologinè gerovë“ - „tai ne tik ligos ar sutrikimo nebuvimas“ [16]. Šis sveikatos apibrèžimas yra nekitęs nuo 1948 m., vadinasi, aktualus bei nekintantis strateginiuose klausimuose. Apibrèžiant sveikatos rekreaciją, galima matyti ir loginę seką, atitinkančią Lietuvos sveikatos 2014-2025 m. programos strateginius tikslus [14]: išplèstinė sąvoka aprépia sveikatos ugdymo klausimus, stiprinimo (prevencijos), saugojimo (prevencijos) ir atgavimo (rekreacijos).
Natūraliosios ir liaudies medicinos koncepto turinys. Teisékūros iniciatyvos reglamentavimo pažymoje [3], antroji iš planuojamos reglamentuoti PAM sričiu yra natūralioji ir liaudies medicina. Jos pažymoje [12]: gamtinių ir fizikiniu faktorių poveikio grupe (kaip pvz., vonios, purvo aplikacijos, aromaterapijos ir kt.), biologinio poveikio paslaugu grupe (kaip pvz., fitoterapija, homeopatija, hirudoterapija ir kt.) bei kūno (kontaktinio) poveikio paslaugų grupè (kaip pvz., akupunktūra, kineziterapija ir kt.), psichosocialinio poveikio paslaugu grupe (kaip pvz., meno terapija, biblioterapija, gyvūnų terapija ir kt.). Darbo grupès suformuluotas apibrèžimas [12] nurodo, jog paslaugu grupe orientuojasi ị ligos negalavimų lengvinimą, iš esmès sukuria specifinị PAM ir konvencinès medicinos sąveikos tipą. Numatomas paslaugų grupès sąrašas turètų atliepti alternatyviojo PAM modelio, arba tikrojo konvencinio modelio principus. Itin kritikuotinas požiūris, jog natūraliosios ir liaudies medicinos prigimtis - tapti tradicinès medicinos dalimi, arba opozicionuoti šiai sričiai. Grižtant prie Pasaulio sveikatos organizacijos nuostatos, jog PAM laikytina atskira medicinos dalimi [6], susiduriama su vienašališka nuostata, jog šiuo apibrèžimu teigiama, jog natūralioji ir liaudies medicina priklauso PAM alternatyviajam modeliui. Tai iš esmès reikštų, jog relaksacinès terapijos, fitoterapija, kineziterapija, balneoterapijos paslaugos, hirudoterapija ir pan., nèra regima kaip taikoma integruotai su tradicine medicina. Tuo tarpu mokslinèje literatūroje galima rasti ne mažai teiginių, jog pvz., hirudoterapija yra laikoma tradiciniu gydymo būdu [17]: dèlių kaip pagalbinès priemonés panaudojimas nuo seniausių laikų aptariamas tokiose konvencinès medicinos srityse kaip abscesų, artrito, glaukomos, miastenijos, trombozès, kai kurių venų ligų, plastinès chirurgijos [18], rekonstrukcinèje mikrochirurgijoje [19]. Tokia pasaulinė praktika verčia suabejoti siūlomu neintegralios sąvokos turiniu.

Siūlomas tobulinimas, atsižvelgiant ì natūraliosios ir liaudies medicinos apimamas paslaugas, galètų būti formuluojamas taip: natūralioji ir liaudies medicina - PAM sritis, skirta kaip pagrindinè ar papildoma priemoné ligos sukeltiems negalavimams palengvinti arba padedanti palaikyti/ atkurti žmogaus fizinę ir psichosocialinę gerovę.

Teigtina, kad platesniu apibrèžimu galima išlaikyti skirtingus PAM modelius, kadangi ir pažymoje $[3,12]$ apibrèžiamas paslaugos turinys gali būti įvairialypis, t.y., kaip tik alternatyvus metodas, kaip integratyvioji medicina, papildomoji medicina šalia konvencinès medicinos, natūralioji ar holistinè. Šiuo atveju platesnè apibrèžtis suponuoja pliuralistiškesni paslaugos kontekstą, kas iš esmès ir atliepia pažymos [3,12] turinị.

Kitos PAM veiklos koncepto turinys. Teisèkūros inicia- 
tyvos reglamentavimo pažymoje [3] trečioji iš planuojamos reglamentuoti PAM sričių yra kita PAM veikla. Kita PAM veikla pažymoje apibrèžiama kaip [12]: praktikos veikla, kurios metu sukuriami produktai gali būti naudojami PAM praktikoje, apimanti biologinio poveikio gaminių grupę, fitoterapijos gaminių grupę ir gyvų organizmų grupę. Šiuo atveju koncepto turinys iš esmès yra glaustas, aiškus ir konkretus, ką ateityje būtina detalizuoti, nes nèra visiškai aiškus šio planuojamo reglamentuoti pogrupio turinys.

\section{Rezultatų aptarimas}

Visame pasaulyje PAM paslaugų poreikis kasmet auga, kinta paslaugu pobūdis, pastebimas tradicinès medicinos metodu derinimas su papildomaisiais metodais $[4,5,20]$. Didejja ne tik pačių paslaugų, tačiau ir PAM sukurtu produktų vartojimas, pvz., dar 2010 metais atliktas tyrimas atskleide, jog daugiau nei puse Europos gyventojų naudojosi papildomosios ir alternatyviosios medicinos forma, o apie 30-50 procentų naudoja PAM metodus gerai savijautai palaikyti [4]. Sistemingų tyrimų, kaip ir tyrimų, reprezentuojančių Lietuvos situaciją, vis dar stokojama [5]. Tačiau, apžvelgus kitus, istorinius tyrimus, kaip, pvz., Spigelblatt, 1994 metais JAV atliktas tyrimas parodé, jog apklausus šeimas, auginančias vaikus su negalia, apie 11 procentu jų naudojosi PAM paslaugomis ar produktais. Pakartotinis tyrimas 2003 metais atskleide, jog tokių šeimų jau buvo 45 procentai [21]. Lietuvos Respublikos Seimo $2014 \mathrm{~m}$. birželio 26 d. nutarimu Nr. XII-964 patvirtintoje Lietuvos sveikatos 2014-2025 metu programoje [14] yra minimos anksčiau patvirtintos sveikatos programos nesėkmès: supratimo stoka darniame visuomenès vystymesi, bendradarbiavimo, sprendžiant klausimus, susijusius su ekonomika, socialine, kultūrine gerove, aplinkosauga bei visuomenès sveikata, kai kurių paslaugų prieinamumo problema mažas pajamas gaunantiems gyventojams, neracionalus sveikatos sistemos išteklių paskirstymas. Dideliu iššūkiu valstybès sveikatos politikai išlieka gyventojų psichikos sveikata bei socialinė atskirtis, atskleidžiant psichosocialiniu faktorių ignoravimą arba nepakankamą ju ịvertinimą medicinos srityje. Minèti sveikatos politikos iššūkiai, naujai formuluojami prioritetiniai tikslai bei aptariamos nesėkmès suponuoja poreikị kalbèti apie tai, jog konvencinè medicina šiai dienai nèra pakankamai parengta atliepti žmogaus gerovès principų psichosocialine prasme, tačiau šią funkciją gali atlikti PAM. Užsienio šalių tyrimai [22] rodo, jog dažnai pacientai PAM suvokia kaip visiškai negalinčią pakenkti gydymo formą, tie patys tyrimo rezultatai gauti ir tyrinejant šeimų, esančių chroniškos vaiko negalios situacijoje [23], kuomet gyvūnų terapija apibūdinama kaip ,natūrali““ intervencijos forma. Šeimų teigimu [23], jeigu gyvūnų terapija ir nepadès, tai ji bent tikrai „nekenksminga“. Moksliniai tyrimai rodo, jog PAM poreikis labiausiai išryškejja tuomet, kai situacinis diskomfortas yra nesikeičiantis, blogejjantis, taip pat, jei konvencinè medicina negali pasiūlyti sprendimo būdų [20]. İdomu, jog papildomoji ir alternatyvioji medicina dažnai taip pat negali pasiūlyti sprendimo būdų [22], tačiau PAM gali pasiūlyti išplèstinę žmogaus gerovès sampratą, kuri sietina su holistine sveikatos percepcija. Pavyzdžiui, atlikti moksliniai tyrimai $[20,21,24]$ rodo, jog neradus pacientą tenkinančio sprendimo tradicinèje medicinoje, pasitenkinimas papildomosios ir alternatyviosios medicinos metodais kartais siekia net 75 procentus. Pacientų pasitenkinimo priežastys glūdi ne ligų išgydyme, o psichologiniuose, socialiniuose bei emociniuose aspektuose, kurie konvencinèje medicinoje vis dar siūlomi rezervuotai [20]. Kita vertus, Lietuvoje atliktas dešimties šeimų tyrimas parodè, jog vaiko cerebrinio paralyžiaus atveju bėgant metams jos nebesiorientuoja ị mediciną kaip svarbiausią paramos grandi, nes jų atveju gydymas neegzistuoja, yra nepasiekiamas, arba šeimos dalyvavimas procese yra itin menkas [25]. Tuo tarpu PAM duoda viltị kitokiais būdais užtikrinti vaikui pasitenkinimą teikianti gyvenimą. JAV atlikti tyrimai rodo, jog iš esmès nei vienas PAM metodas neeliminuoja autizmo simptomatikos iš esmès, todèl galvojama, jog PAM svarba kyla iš kompleksinès pagalbos ne tik vaikui, bet ir visai šeimai siekimo. Šeimos, auginančios vaikus su autizmo spektro sutrikimu, teige, jog PAM paslaugų siekè labiau dèl savo emocinès paramos ir fizinio komforto poreikio [21,26].

Taigi, aptarta problematika verčia grižži i sveikatos visuminę sampratą bei santykị su visuminès žmogaus gerovės supratimu. XII-964 patvirtintoje Lietuvos sveikatos 2014-2025 metų programoje yra išskiriami keturi strateginiai tikslai, orientuoti į žmogaus gerovès stiprinimą: socialinès atskirties mažinimas, palankios aplinkos kūrimas, sveika gyvensena bei paslaugos, orientuotos i gyventojų poreikius $[14,15]$. Pasaulio sveikatos organizacijos Europos regiono komiteto metinès sesijos 2012 m. priimta Europos sveikatos politikos strategija „Sveikata 2020“ taip pat orientuojasi į holistiškumą bei siūlo sveikatą vertinti, atkreipiant dèmesị ị: visuminị požiūrị sveikatą lemiančius veiksnius, ị efektyvių ir veiksmingų būdų igyvendinimą naudojantis partnerystès, komunikacijos ir technologijų galimybėmis. Dokumente kalbama, jog šie apibrèžimai neturètų būti suvokiami kaip konvencinès medicinos prieštara, anaiptol, teigiama, kaip minètų PAM modelių integratyvi sąveika [27]. Analizuota planuojamos reglamentuoti PAM sąvokų turinio analizė atskleide, jog reikalaujama platesnių diskusijų: psichosocialinių faktorių eliminavimas vèl gali atkartoti buvusios sveikatos strategijos klaidas bei neefek- 
tyviai veikiančias programas. Mokslinių tyrimų diskursas atskleidè, jog psichoemociniai, psichosocialiniai faktoriai PAM yra esminiai, dèl kurių kreipiamasi esant net chroniškos ligos atveju, dažnai ieškant pagalbos net ne pačiam pacientui, o jo socialiniam tinklui - šeimos nariams, artimiesiems.

\section{Išvados}

1. Papildomosios ir alternatyviosios medicinos paslaugu reglamentavimas Lietuvoje yra neabejotinai svarbus visai sveikatos sistemai. Didžioji dalis pacientų jau yra išmėginusi PAM metodus arba vartoja PAM produktus, naudojasi paslaugomis. Patys medikai pripažista, kad praktikoje prie konvencinès medicinos tenka pasiūlyti pacientams PAM paslaugas ar produktus [4], todèl reglamentavimas teisiškai išspręstų daugelį probleminių klausimų.

2. XII-964 patvirtintoje Lietuvos sveikatos 2014-2025 metu programoje yra išskiriami keturi strateginiai tikslai, orientuoti i žmogaus gerovès stiprinimą, o Pasaulio sveikatos organizacijos Europos regiono komiteto metinės sesijos $2012 \mathrm{~m}$. priimtoje Europos sveikatos politikos strategijoje „Sveikata 2020“ kalbama apie holistinị požiūrị ị sveikatą, aprépiant fizinius, socialinius, psichologinius aspektus. Moksliniai tyrimai rodo, jog psichosocialiniai aspektai dažnai yra svarbiausi, siekiant PAM paslaugų, todèl derètų galvoti apie konvencinès medicinos ir PAM sistemų dermę, atliepiant strategini tikslą dèl tarp sektorinio bendradarbiavimo.

3. Pažymoje [3] suformuluoti reglamentavimo laukiantys konceptai (sveikatos rekreacija, natūrali ir liaudies medicina, kita PAM veikla) savo turiniu tik iš dalies atitinka numatomu paslaugu turini. Teigtina, kad viena esminių ateities problemų reglamentuojant šią naują sriti yra sampratos slinktis: ar PAM būtina vadovautis medicininiu-klinikiniu požiūriu, ar akcentuoti daugiau psichosocialinių aspektų? Būtina diskutuoti ir apie profesines grupes bei licencijavimą, kadangi ne visi psichosocialiniai aspektai gali būti atliepti, žvelgiant iš tradicinès medicinos sistemos perspektyvos. Svarbu nepamiršti PSO rekomendacijos PAM laikyti labiau atskira medicinos bei sveikatos apsaugos dalimi, nei tradicinès medicinos dalimi [6], tuo pačiu aspektų atliepimą. išlaikant kolaboratyvų modelị ir santykị, o ne supriešinimą. Tokiu būdu galima suderinti valstybès teisinį-medicininį reguliavimą, saugių ir integratyvių paslaugų ir produktų teikimą pacientams.

\section{Literatūra}

1. Lietuvos Respublikos sveikatos sistemos įstatymas. $1994 \mathrm{~m}$. liepos 19 d. Nr.I-552. Valstybės žinios". Vilnius. 1994; 63-1231 (neoficialus įstatymo tekstas).
2. Projektas Sveikatos netolygumų ir nustatymo mažinimo gebejjimų stiprinimo modelio sukūrimas". Kodas NOR-LT11SAM-01-TF-02-001.Vykdytojas - Lietuvos sveikatos mokslų universitetas. 2014-2016 m. Prieiga per internetą: http://www. sam.lrv.lt, [žiūrèta 2016-05-10]

3. Lietuvos Respublikos Vyriausybès Kanceliarijos raštas Sveikatos apsaugos ministerijai "Dėl prioritetinès iniciatyvos - reglamentuoti netradicinès medicinos praktiką - numatomo teisinio reguliavimo vertinimo pažymos". 2015-11-27, Nr.10-4243.

4. Špokienė I. Papildomosios ir alternatyviosios medicinos teisinio reguliavimo Lietuvoje probleminiai aspektai. Sveikatos politika ir valdymas, 2011; 1(3):170-196.

5. Kreivinienė B, Vaičekauskaitè, R. Papildomoji ir alternatyvioji medicina Lietuvoje: reglamentavimas ir neigalius vaikus auginančių šeimų poreikiai. Visuomenès sveikata, 2014; 24(4): $11-18$.

6. Sherman H, Castro G, Fletcher M, Hatlie M, Hibbert P, Jakob R. et al. Towards an International classification for patient safety: the conceptual framework. International Journal of Healthcare Quality 2009; 21(1):2-8.

https://doi.org/10.1093/intqhe/mzn054

7. Sveikatos apsaugos ministerija. Prioritetinès teisèkūros iniciatyvos - reglamentuoti netradicinès medicinos praktiką numatomo teisinio reguliavimo poveikio vertinimo pažyma (neoficialus tekstas). Vilnius, 2015.

8. Sinkevičius V, Vaičekauskaitė R, Kirkutis A, Serafinas D. Vaizdinių terapijos konceptualizavimas papildomos, alternatyvios ir tradicinès medicinos kontekste. Sveikatos mokslai, 2014; 24(4):11-16.

https://doi.org/10.5200/sm-hs.2014.062

9. Harris PE, Cooper KL, Relton C, Thomas KJ. Prevalence of complementary and alternative medicine (CAM) professional practice and safety: a consensus building workshop. European Journal of Integrative Medicine 2011; 3:49-53.

https://doi.org/10.1016/j.eujim.2011.05.011

10. Howarth D. Discourse. Buckingham (Philadelphia): Open University Press. 2000.

11. Wiese M, Oster C, Pincombe J. Understanding the emerging relationship between complementary medicine and main stream healthcare: A review of the literature. Health 2010; 14(3): 326-342.

https://doi.org/10.1177/1363459309358594

12. LR Sveikatos apsaugos ministerija Dèl prioritetinès iniciatyvos - reglamentuoti netradicinés medicinos praktiką - numatomo teisinio reguliavimo poveikio vertinimo pažymos derinimo". 2015-11-12, Nr.(1.1.20-32)10-10078.

13. Lietuvos sveikatos politikos strateginiai aspektai. V Nacionalinė sveikatos politikos konferencija. 2006. Prieiga per internetą: http://www.sam.lt/repository/dokumentai/sveikatos_politika/v\%20konferencija\%20ministrui\%205.ppt, [žiūrèta 2016-05-01].

14. Lietuvos Respublikos Seimo 2014 m. birželio 26 d. nutarimas 
Nr. XII-964 Dėl Lietuvos sveikatos 2014-2025 metų programos patvirtinimo". Prieiga per internetą: <https://www.e-tar. 1t/portal/1t/legalAct/85dc93d000df11e4bfca9cc6968de163>, [žiūrèta 2016-05-03].

15. Kiselienè I. Pagrindinès Lietuvos sveikatos 2014-2025 metu programos igyvendinimo sèkmès prielaidos. Visuomenès sveikata, 2014; 3(66): 5-9.

16. Preamble to the Constitution of the World Health Organization as adopted by the International Health Conference, New York, 19-22 June, 1946; signed on 22 July 1946 by the representatives of 61 States (Official Records of the World Health Organization, no. 2, p. 100) and entered into force on 7 April, 1948.

17. Karadag AS, Calka O, Akdeniz N, Cecen I. A case of irritant contact dermatitis with leech. Cutan Ocul Toxicol 2011;30(3): 234-5.

https://doi.org/10.3109/15569527.2010.547543

18. Singh AP. Medicinal leech therapy (hirudotherapy): a brief overview. Complement Therapy Clinical Practice 2010; 16(4): 213-5.

https://doi.org/10.1016/j.ctcp.2009.11.005

19. Knobloch K, Gohritz A, Busch K, Spies M, Vogt PM. Hirudo medicinalis-leech applications in plastic and reconstructive microsurgery - a literature review. Handchir Mikrochir Plast Chir 2007; 39(2): 103-7.

https://doi.org/10.1055/s-2007-965138

20. Committee on children with disabilities, counseling families who choose complementary and alternative medicine for their child with chronic illness or disability. Pediatrics 2001; 107(3): 598-601.

21. Hyman SL, Levy SE. Introduction: novel therapies in developmental disabilities - hope reason, and evidence. mental retardations and developmental disabilities. Research Reviews 2005; 11:107-109.

22. Carlson MJ, Krahn G. Use of complementary and alternative medicine practitioners by people with physical disabilities: Estimates from a National US Survey. Disability and Rehabilitation 2006; 28(8): 505-513.

https://doi.org/10.1080/09638280500212062

23. Kreiviniene B. Social support: voices of families in severe disability situation. Lambert Academic Publishing: Germany, 2012.

24. Wong HHL, Smith RG. Patterns of complementary and alternative medical therapy use in children diagnosed with autism spectrum disorders. Autism \& Developmental Disorders 2006; 36:901-909.

https://doi.org/10.1007/s10803-006-0131-0

25. Kreivinienẻ B, Perttula J. Delfinų terapija Lietuvoje: lūkesčiai šeimų, auginančių vaikus su kompleksine negalia. Specialusis ugdymas. Šiauliai, 2012; 2 (27): 142-152.

26. Hanson E, Kalish LA, Bunce E, Curtis C, McDaniel S, Ware J, Petry J. Use of complementary and alternative medicine among children diagnosed with autism spectrum disorder. Autism \& Developmental Disorders 2007; 37: 628-636. https://doi.org/10.1007/s10803-006-0192-0

27. Jakab Z, Tsouros AD. "Sveikata 2020"- siekiame sveikatos ir darnaus vystymosi dabartinèje Europoje. Visuomenès sveikata, 2013; 4(63): 5-12.

\section{REGULATION OF COMPLEMENTARY AND ALTERNATIVE MEDICINE IN LITHUANIA: ISSUES AND PERSPECTIVES}

\section{B. Kreivinienė, J. Vaičiulienė, S. Norkienė, G. Skirutienė}

Key words: complementary and alternative medicine, regulation, wellness.

Summary

Lithuania and throughout Europe, the apparent complementary and alternative medicine (here in after - PAM) for demand growth, perceived exploitation potential at-regulated jurisdiction. The debate stems from the concept of the PAM, domain definition, emerging services methodologies, so-called standards, professional qualifications, licensing procedures.

The aim - to analyse present situation of regulation of the complementary and alternative medicine, problems and perspectives.

Methods. Descriptive literature analysis bringing to the light differences in understanding the main concepts of health, human wellness and CAM regulation. The insights are given from today's discussions on the regulation documents and different scenarios of regulation in the Ministry of Health of the Republic of Lithuania.

Results. World Health Organization conceptualize understanding of human health as complete physical, social and spiritual wellness in orientation that a concept of health compounds perception of holistic medicine. It is stated in Health strategy of the European Union (third program, 2014-2020) that human healthiness, prevention and recreational health functions are recommended to apply in all sphere politics. Complementary and alternative medicine has a strong background to become an aspect of holistic understanding in medicine via different fields such as recreation, natural (folk) medicine and others. However present situation has not reached a consensus in regulation because of occurring discussions and issues as well as not yet solved questions. The same importance is to highlight integrity between traditional and complementary and alternative medicine. Conclusion. Descriptive literature analysis brought to the light different strategies with/without similarities in regulation complementary and alternative medicine in Europe; the diverse spheres of medical practice is held complementary and alternative medicine in different countries. However, the balance in regulation could be found in linking the ideas of World Health Organization and strategy of European Region Committee of health politics accepted in annual session 2012 "Health 2020" where the concepts of integrity and holistic medicine are emphasized.

Corespondence to: brigita.kreiviniene@ku.lt

Gauta 2016-12-01 